\title{
Net Balance Analysis Relationship of Learning Interests and Student Learning Outcomes of Teacher Explanation Skills in Medan City
}

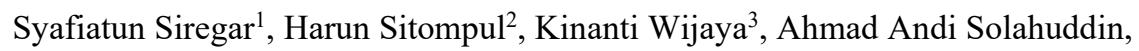 \\ Mey Theresia Naibaho \\ \{syafiatunsiregar@gmail.com ${ }^{1}$,prof_runsit@yahoo.co.id ${ }^{2}$, kinanti.w@gmail.com 3 \} \\ Universitas Negeri Medan, Jurusan Pendidikan Teknik Bangunan, Medan ${ }^{1,2,3}$ \\ syafiatunsiregar@gmail.com
}

\begin{abstract}
This study aims to analyze the relationship of learning interest and student learning outcomes with the teacher's explaining skills using Chi-Square analysis and to determine the level of student optimism towards the teacher's explaining skills using the net balance method. Based on the trial instrument the results obtained; (1) The teacher's explaining skills there were 24 valid statements, (2) The Learning Interest variable there were 23 valid statements, (3) The Learning Outcomes variable with 31 valid questions. The results obtained are that there is a relationship between the skills of explaining teachers with student interest in learning with the acquisition of Chi-Square count $51.332>$ ChiSquare table 37.65. In contrast, there was no relationship between the teacher's explaining skills and the learning outcomes obtained with the Chi-Square count $_{\text {calculated }} 18.710<\mathrm{Chi}^{-}$ Square table 37.65. The net balance results contained 6 statements of students' pessimistic perceptions of the teacher's explaining skills.
\end{abstract}

Keywords: Teacher's Explaining Skills, Interest In Learning, Learning Outcomes.

\section{Introduction}

Vocational High School (SMK) is one of the secondary level educational institutions that manage vocational education. To achieve the educational goals in Vocational Schools is formulated from Government Regulation of the Republic of Indonesia Number 19 of 2005, namely; (1) Learn to have faith and be devoted to God Almighty; (2) Learn to understand and appreciate in developing an attitude of professionalism; (3) Learning to be able to carry out and act effectively; (4) Learn to live together and be useful to others; (5) Learning to build and find identity through an active, creative, effective and enjoyable learning process; (6) Become a midlevel workforce to fill current and future business and industrial needs. Government Regulation $19 / 2005$ as a Vocational Guideline is expected to produce mid-level skilled workers in accordance with their area of expertise.

SMK in Medan City of North Sumatra Province in the Building Design and Information Design (DPIB) expertise program has a curriculum that has been prepared based on their respective engineering training program. The engineering education and training programs in Vocational Schools are divided into 3 groups, including (1) Normative Training Programs, (2) Adaptive, and (3) Productive. Of these three training programs, it is the productive training program that 
is a subject of expertise that is directly related to student skills. Specifically to see the quality of learning, ideally, students master all subjects contained in the Normative Training Program, Adaptive Training Program, and Productive Training Program. Drawing techniques contained in the Productive Training Program need attention because this subject discusses drawing manually. This subject is very useful because it is a vocational requirement that has a close relationship with other subjects related to the Productive Training Program.

The Drawing techniques are directly related to science and technology (Science and Technology), especially in building techniques and daily life that have an important role in improving quality human resources. Drawing Engineering needs to be taught and mastered by all students in vocational and tertiary institutions. This subject aims to make students have the basic capital for manual drawing and drawing with software so that students are expected to master the subject of drawing techniques.

The reality is not as expected, this can be seen from the low level of student mastery of Drawing Techniques in the SMK environment in Medan, as can be seen in Figure 1 below. Figure 1. Shows that there are $22.64 \%$ of students who have not succeeded (not competent), and $77.36 \%$ of students who have succeeded (competent and quite competent). Overall, learning outcomes have not shown the success of a class. Mastery learning can be categorized to be successful if $>$ $85 \%$ of students are competent.

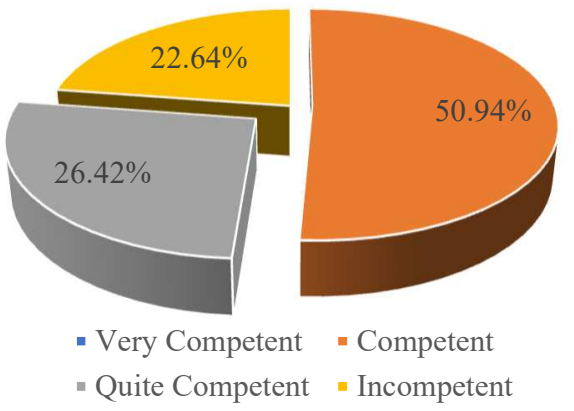

Fig. 1. Learning Outcomes of Drawing Techniques SMK in Medan City, 2019

The students' success in learning to draw techniques is also largely determined by internal factors, namely student learning interest. Because the learning material does not match the interests of students, students will not be encouraged to study as well as possible because there is no attraction for him. Learning material that attracts students' interest is easier to memorize and store, because interest activities changed. Interest can and does function as a powerful driving force. For this reason, an effort should be made to explore, grow and foster students' interest in Engineering Drawing lessons.

The purpose of this study is to:

a. To find out the relationship between teacher's explaining skills and interest in learning

b. To find out the relationship between teacher's explaining skills and learning outcomes

c. To analyze students' perceptions of the teacher's explaining skills using net balances. 


\section{Literature Review}

\section{The Nature of Learning Outcomes in Drawing Techniques}

Learning outcomes is the level of student ability in the learning process states learning outcomes are a result of the learning process by using measurement tools. Measurement of learning outcomes can take the form of tests arranged in a planned manner, both written tests, oral tests and tests of deeds. Learning outcomes are a change in an individual. These changes are not only about knowledge but also shape the skills and personal self-appreciation of individuals. Learning outcomes are the acquisition of something new in the behavior after someone has done the learning activities. The success of student learning in achieving teaching objectives can be realized by the acquisition of values obtained at the end of the learning process. Learning is a business process that is done by someone as a whole to obtain a change in a new behavior. Changes in behavior are as the result of his experience in interactions with the environment and interactions in learning.

Drawing techniques are the subjects of training taught in the Vocational Building Modeling and Information Design Skills Program (DPIB). The subjects aim at assigning how to draw a construction manually. With competent students from these subjects, students will be able to continue their studies in building engineering majors with deeper knowledge.

Drawing techniques are productive subjects that lead to basic mastery in drawing techniques. Teaching and learning activities on these subjects carried out in the classroom and divided into two namely theory and practice. The theory of drawing techniques becomes fundamental and important, where students gain basic knowledge about the principles in drawing basic techniques and become a source of knowledge to understand the practice. Practical activities are concrete steps and proof of what has been taught in theory, in other words, practical activities are work based on theory.

\section{Students' Perceptions About Teacher Explaining Skills}

Perception is a process that is experienced by sense, which is the process of receiving a stimulus by an individual through the sense organ or also called a sensory process. Perception is the process of receiving an object's excitement, quality, the relationship between symptoms, and events until the stimulus is realized and understood [1]. Perception is an experience about objects, events or relationships obtained by concluding information and interpreting messages. Perception is giving meaning to sensory stimulus (sensory stimulus). Based on the definition above that perception is not a real thing. However, perception is a concentration of something that leaves a message to someone.

During the learning process, verbal and verbal communication in the classroom includes face-to-face interaction and communication that is needed between the participants involved in the class [2]. In this face-to-face interaction, the teacher uses verbal and non-verbal language to communicate the expectations of students, material, strong interactions between students and teachers, creating a comfortable atmosphere, giving praise, personal approach, showing discipline, good listener, and other things which are communicative to bring about a conducive and pleasant learning atmosphere

The purpose of the teacher using communication in the classroom is to (1) obtain relevant knowledge from students, (2) to respond and provide input to the things students ask about and (3) to describe learning experiences. It is hoped that with class communication, teacher communication skills will be identified, teachers will become more aware of their communication skills and communication patterns currently in their classrooms and will be able to evaluate whether these patterns provide opportunities for them students to study [3]. By 
focusing on more than one teacher's explaining skill questions that they use when teaching, teachers will be able to practice and monitor the use of their communication skills not only as important input for their students but also to achieve more effective teaching when doing lessons. In addition, there are no studies examining how teacher language or communication skills contribute to their ESL classroom communication in the context of their teaching. In this study, speaking and explaining teacher skills, or using the term Bleach, communication skills are seen in the context in which what and how they are used, and as a contribution to the integration of teacher language as verbal communication skills (delivery of material) as a hierarchy of decisions and automatic actions which is used as an integrated whole, the lower one depends on the higher [4]. In this study, several statements such as the ability to explain the teacher, including attracting the attention of students; provide questions and answers, manage mistakes, explain, communicative language, and nonverbal communication skills are explored. Teacher and student communication such as socializing, directing, giving instructions and summarizing are important [5]. The most common communication skills used by teachers in the classroom are explaining the material, asking questions and raising questions or answers. The teacher in the class must be able to use high questioning skills. The teacher asks questions to assess student understanding and increase student involvement during the learning process. The teachers use communication skills that are less than socializing skills in teaching. In addition, nonverbal communication skills are also very important to be used by teachers.

\section{Interest to Learn}

Interest is the willingness of the soul that is active to receive something from outside. Each lesson must be strived to be able to attract students. Interest persists to pay attention to end enjoy some activity or content. Interest is a feeling of preference and a sense of interest in a thing or activity, without anyone asking. Interest is basically the acceptance of a relationship between oneself and something outside of oneself. Big interest is the effect on learning because if the lesson learned is not in accordance with the interests of students, the results are not satisfactory. Interest is the tendency of a subject to settle, feel interested in a particular subject area of study and feel happy studying the material. Someone who is interested in activity will pay attention to the activity consistently with pleasure.

teacher has an important role in increasing and arousing student interest in learning. To get the best teaching results in the learning process the teacher is must always try to arouse the interests of the students so that all of their attention is focused and focused on the learning material after being taught.

There are several ways to arouse interest in learning, namely (1) arising of a need, (2) connecting with past experience problems, (3) giving an opportunity to get good results, and (4) using various forms of teaching.

Those interest concerns activities freely chosen by individuals. Interest or interest involves the symptoms of the process associated with objects or activities that stimulate an individual's feelings of pleasure. Interest is associated with needs, for example, a man who is developing in need of physical growth will take an interest in physical activities such as soccer, volleyball or other activities that can accelerate his physical growth. 


\section{Methodology}

This research was conducted at the State Vocational School in Medan City Building Design and Information Design Skills Program (DPIB) in 2019 Engineering Drawing subjects. The research method used by researchers in this study was a descriptive research type correlation study. This study uses three variables that are the skills of explaining the teacher, interest in learning, and learning outcomes. The crosstab analysis was carried out using SPPS version 23 which links a teacher's explaining skills with an interest in learning and the relationship between teachers explaining skills and learning outcomes. Next to the analysis of perception using net balance analysis

Data processing is performed using the net balance method, namely by calculating the difference between the percentage of the number of respondents who give 'Always and Often' answers with the percentage of the number of respondents who give answers' Rarely and Never 'and ignoring the answers' Sometimes ". As for measuring the perception of teacher activity with student learning interest and learning outcomes if the results are positive then students optimistic for the statements given otherwise will be pessimistic about the statement of minus value.

\section{Results and Discussion}

The study was conducted at 3 SMKs in Medan city. The population is all students in class $\mathrm{X}$ of the Building Design and Information Design (DPIB) expertise program while the sample is taken as many as 98 students representing 3 public SMKs in Medan. Assessment of the ability to explain the teacher was done by giving answers in the category Always, Often, Sometimes, Rarely, and Never. The rating scale uses a Likert scale with the highest range of 5 and lowest 1 . The results of the frequency distribution obtained data as follows in Table 1 .

Table 1. Research Frequency Distribution Results

\begin{tabular}{llrrr}
\hline & & $\begin{array}{c}\text { Teacher's } \\
\text { Explaining Skill }\end{array}$ & $\begin{array}{c}\text { Interest To } \\
\text { Learn }\end{array}$ & $\begin{array}{c}\text { Learning } \\
\text { Outcomes }\end{array}$ \\
\hline \multirow{2}{*}{$\mathrm{N}$} & Valid & 98 & 98 & 98 \\
\cline { 2 - 5 } & Missing & 0 & 0 & 0 \\
\hline Mean & 91,4286 & 80,8673 & 19,7857 \\
\hline Median & 92,0000 & 83,0000 & 19,0000 \\
\hline Std. Deviation & 9,73780 & 7,90750 & 3,57035 \\
\hline Minimum & 71,00 & 59,00 & 14,00 \\
\hline Maximum & 112,00 & 96,00 & 27,00 \\
\hline
\end{tabular}

Teacher's explaining skills have the lowest range of 71 and the highest value of 112 out of 24 valid statements distributed to students. Learning interest has a range that has the lowest values 57 and the highest value 96 of 23 valid statements distributed to students. Learning outcomes have the lowest values 14 and the highest value of 27 of 31 valid statements distributed to students. From the table, it is found that the average ability to explain the teacher is equal to 91.46 or $76.21 \%$. Figure 1, Figure 2 and Figure 3 explain the frequency distribution of each variable tested. 


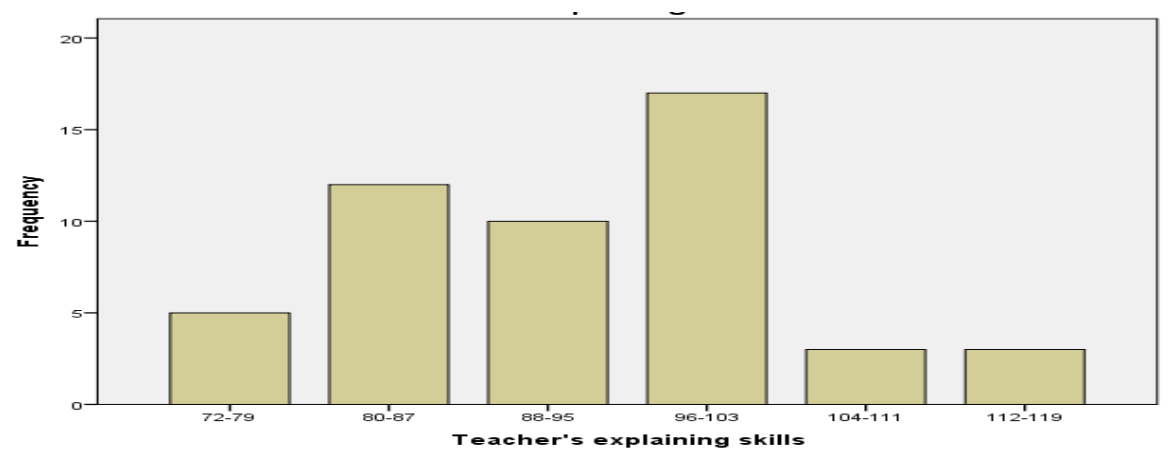

Fig. 2. Results of Frequency Distribution of Teacher Explaining Skills

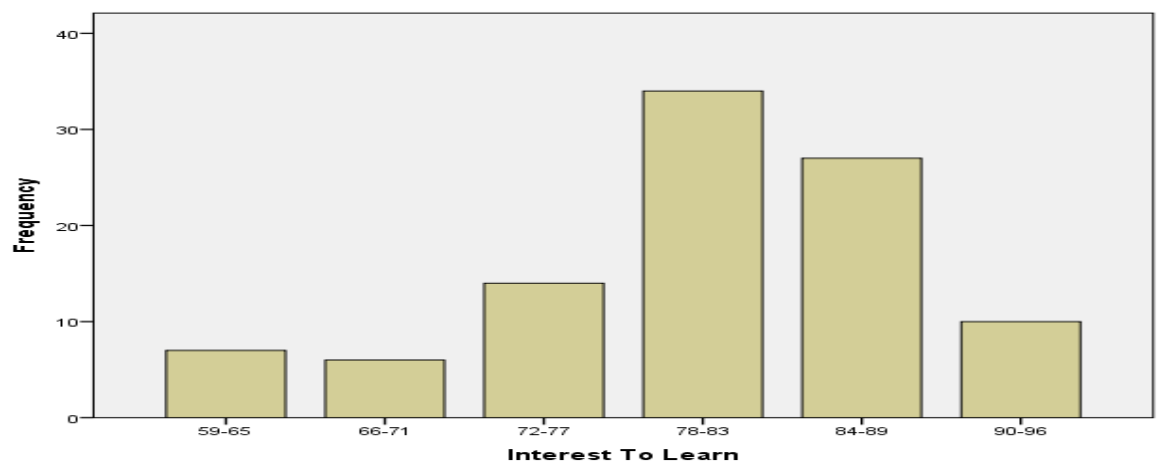

Fig. 3 Learning Interest Frequency Distribution Results

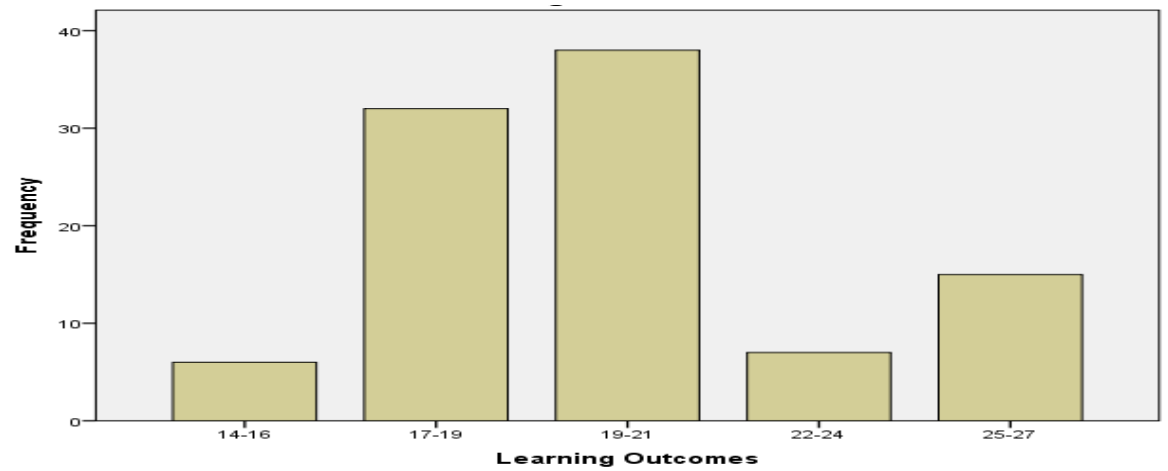

Fig. 4. Results of Frequency Distribution Learning outcomes

The cross-tabulation analysis was carried out, namely between the variables Explaining the Teacher's Skills with Interest in Learning and the Skills Explaining the Teacher's Learning Outcomes in Drawing Techniques. The results can be seen in Table 2 and Table 3 . Then the crosstab analysis shown in Table 4 and Table 5.

Table 2 Results Of Crosstab Skills Explain Teacher And Interest In Learning 


\begin{tabular}{lcccccccc}
\hline & \multicolumn{1}{c}{$59-65$} & $66-71$ & $72-77$ & $78-83$ & $84-89$ & $90-96$ & 8 \\
\hline Teacher's & $71-77$ & 0 & 3 & 0 & 3 & 1 & 1 & 21 \\
\cline { 2 - 9 } $\begin{array}{l}\text { Learning } \\
\text { Skill }\end{array}$ & $78-84$ & 4 & 1 & 1 & 10 & 2 & 3 & 15 \\
\cline { 2 - 9 } & $85-91$ & 0 & 0 & 6 & 7 & 1 & 1 & 25 \\
\cline { 2 - 9 } & $92-98$ & 2 & 2 & 3 & 4 & 10 & 4 & 23 \\
\cline { 2 - 9 } & $99-105$ & 0 & 0 & 3 & 9 & 10 & 1 & 6 \\
\hline Total & $106-112$ & 1 & 0 & 1 & 1 & 3 & 0 & 98 \\
\hline
\end{tabular}

Table 3 Crosstab Analysis Explaining Skills And Interest In Learning

\begin{tabular}{lccc}
\hline & Value & df & $\begin{array}{c}\text { Asymptotic Significance } \\
\text { (2-sided) }\end{array}$ \\
\hline Pearson Chi-Square & $51,332^{\mathrm{a}}$ & 25 &, 001 \\
\hline Likelihood Ratio & 50,724 & 25 &, 002 \\
\hline Linear-by-Linear Association & 3,201 & 1 &, 074 \\
\hline N of Valid Cases & 98 & & \\
\hline
\end{tabular}

a. 29 cells $(80,6 \%)$ have expected count less than 5 . The minimum expected count is, 37 .

From Table 3 the Chi-Square count $=51.332$ while the Chi-Square table $=37.65(\mathrm{df}=$ 25). Expect Chi-Square count $>$ Chi-Square $_{\text {table }}$ which means that Ho was rejected and Ha was accepted which should be related to the skill of explaining the teacher and the interest in learning According to Kogut \& Silver, 2009; Kazi et al, 2012), during the learning process it was very important verbal and non verbal communication in class. The intended communication is the interaction or communication between students and participants. In line with Farrell (2009) that states the purpose of teachers using communication in the classroom is to foster and increase student's learning interest during the learning process. Therefore the teacher's explaining skills are closely related to students' interest in learning. Teachers must be able to foster interest in learning in order to obtain optimal learning outcomes.

Table 4. Results Of Crosstab Skills Explain Teacher And Learning Outcomes

\begin{tabular}{|c|c|c|c|c|c|c|c|c|}
\hline & & \multicolumn{6}{|c|}{ Learning Outcomes } & \multirow[t]{2}{*}{ Total } \\
\hline & & $13-15$ & $16-17$ & $18-20$ & $21-22$ & $23-25$ & $26-28$ & \\
\hline \multirow{6}{*}{$\begin{array}{l}\text { Teacher's } \\
\text { Learning } \\
\text { Skill }\end{array}$} & $71-77$ & 0 & 2 & 4 & 0 & 1 & 1 & 8 \\
\hline & $78-84$ & 2 & 5 & 7 & 1 & 1 & 5 & 21 \\
\hline & $85-91$ & 2 & 4 & 4 & 3 & 1 & 1 & 15 \\
\hline & $92-98$ & 2 & 3 & 13 & 1 & 3 & 3 & 25 \\
\hline & $99-105$ & 0 & 8 & 8 & 3 & 1 & 3 & 23 \\
\hline & $106-112$ & 0 & 2 & 2 & 1 & 1 & 0 & 6 \\
\hline Total & & 6 & 24 & 38 & 9 & 8 & 13 & 98 \\
\hline
\end{tabular}

Tabel 5. Results Of Crosstab Skills Explain Teacher And Learning Outcomes

\begin{tabular}{lrrr}
\hline & Value & df & $\begin{array}{c}\text { Asymptotic Significance } \\
\text { (2-sided) }\end{array}$ \\
\hline Pearson Chi-Square & $18,710^{\mathrm{a}}$ & 25 &, 811 \\
\hline Likelihood Ratio & 21,698 & 25 &, 653 \\
\hline Linear-by-Linear Association &, 086 & 1 &, 770 \\
\hline N of Valid Cases & 98 & & \\
\hline
\end{tabular}

a. 29 cells $(80,6 \%)$ have expected count less than 5 . The minimum expected count is ,37. 
From Table 5 Chi-Square count $=18.710$ while Chi-Square table $=37.65(\mathrm{df}=25)$. This means

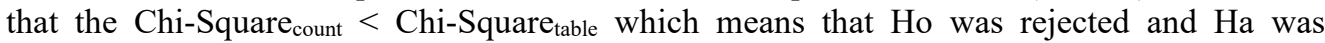
accepted, which means there is no relationship between the skill of explaining the teacher and the learning outcomes. Slameto (2010: 54) states the factors that influences learning outcomes consist of internal factors and external factors. Internal factors are factors that originate in the individual who is learning, namely physical, psychological and fatigue. External factors are factors that exist outside the individual namely family, school, and community (environmental) factors. Therefore the teacher's explaining skill has no effect on student learning outcomes.

Tabel 5. Results of Net Balance Analysis Teacher's Explaining Skills

\begin{tabular}{|c|c|c|c|c|}
\hline \multirow{2}{*}{ No } & \multicolumn{2}{|c|}{ Answer } & \multirow{2}{*}{$\begin{array}{c}\text { Net } \\
\text { Balance }\end{array}$} & \multirow{2}{*}{ Result } \\
\hline & Up & Down & & \\
\hline 1 & 13 & 4 & 9 & Optimistic \\
\hline 2 & 13 & 4 & 9 & Optimistic \\
\hline 3 & 6 & 6 & 0 & Optimistic \\
\hline 4 & 11 & 4 & 7 & Optimistic \\
\hline 5 & 8 & 4 & 4 & Optimistic \\
\hline 6 & 4 & 10 & -6 & Pessimistic \\
\hline 7 & 17 & 0 & 17 & Optimistic \\
\hline 8 & 7 & 5 & 2 & Optimistic \\
\hline 9 & 8 & 10 & -2 & Pessimistic \\
\hline 10 & 7 & 4 & 3 & Optimistic \\
\hline 11 & 3 & 14 & -11 & Pessimistic \\
\hline 12 & 8 & 6 & 2 & Optimistic \\
\hline 13 & 12 & 4 & 8 & Optimistic \\
\hline 14 & 12 & 4 & 8 & Optimistic \\
\hline 15 & 8 & 4 & 4 & Optimistic \\
\hline 16 & 12 & 1 & 11 & Optimistic \\
\hline 17 & 5 & 11 & -6 & Pessimistic \\
\hline 18 & 12 & 2 & 10 & Optimistic \\
\hline 19 & 12 & 1 & 11 & Optimistic \\
\hline 20 & 11 & 4 & 7 & Optimistic \\
\hline 21 & 9 & 7 & 2 & Optimistic \\
\hline 22 & 5 & 7 & -2 & Pessimistic \\
\hline 23 & 4 & 12 & -8 & Pessimistic \\
\hline 24 & 7 & 7 & 0 & Optimistic \\
\hline \multicolumn{2}{|c|}{ Optimistic } & & & 18 \\
\hline Pess & istic & & & 6 \\
\hline
\end{tabular}

Net Balance analysis is carried out to assess students' perceptions of the learning process undertaken. Net balance analysis performed by looking at valid instruments. There are 24 valid instruments for the teacher's ability to explain to the teacher. Net balance done by reducing the value of 'up' (Frequently and Always) by the value 'down' (Rarely and Never). Furthermore, a value of $>0$ will be considered optimistic and a value of $<0$ will be considered pessimistic about the questions were given.

Table 6 shows the results of the net balance analysis skills for explaining teachers. From these results it was found that there are 6 questions that are pessimistic about the ability to explain the teacher, namely in (1) When explaining the subject, the teacher uses language that is difficult for students to understand, (2) The teacher does not care about students' 
understanding of the subject matter described, (3 ) Before implementing the learning process, the teacher does not need to inform the subject matter to be explained, (4) The teacher does not need to remember students to repeat at home the lesson material that has been explained, (5) The teacher never gives an opportunity to students to ask about the subject matter which is not yet clear, (6) The teacher never gives assignments to the material described. Seeing the description of the statement given with students' perceptions of the skills of explaining the teacher needs to be improved both from the teacher's internal and external teachers.

\section{Acknowledgements}

This research was a joint work of several lecturers majoring in Building Engineering Education assisted by students who carry out research for thesis reports. This research will not work well without the support of various parties. Gratitude was conveyed to the Dean of the Faculty of Engineering Unimed, Prof. Dr. Harun Sitompul, M. Pd. who acted as validator and who gave a lot of input in writing the report. A sincere greeting was conveyed to student Mey Theresia Naibaho hopefully, you will succeed in achieving your goals. Furthermore, the gratitude is conveyed to the principal and teachers of State Vocational High School 2, State Vocational High School 5 and Provsu National Vocational School who provided data and helped this research.

\section{References}

[1] Irwanto. Psikologi Umum. Jakarta: Gramedia Pustaka Utama (1994).

[2] Kogut, G. \& Silver, R. E. Teacher Talk, Pedagogical Talk and classroom Activities. Proceedings of the Redesigning Pedagogy (2009).

[3] Farrell, T. S. Talking, listening, and teaching: A guide to classroom communication. Canada: Corwin (2009).

[4] Bygate, M. Speaking. Oxford: Oxford University Press (2003).

[5] Fahainis Mohd. Yusofa, Haslina Halima, Understanding Teacher Communication Skills, Procedia - Social and Behavioral Sciences 155, 471 - 476 (2014).

[6] Arikunto, S..Prosedur Penelitian Suatu Pendekatan Praktik. Edisi Revisi. Jakarta: PT. Rineka Cipta (2013).

[7] Atmadi, A, dan Y. Setyaningsih, Transformasi Pendidikan Memasuki Millenium Ketiga, Yogyakarta: Kanisius (2000).

[8] Hamalik, Oemar. Kurikulum dan Pembelajaran. Jakarta: Bumi Aksara (2011).

[9] Kazi, E. H., Abdul Razak, A. Z. \& Mosa, F. Z Excellent teachers and their job satisfactions: An Analysis at Malaysia's Standpoint. International Journal of Academic Research in Progressive Education and Development October 2012, 1(4), 1-16 (2012). 
[1] Kunandar. 2008. Langkah Mudah Penelitian Tindakan Kelas Sebagai Pengembangan Profesi Guru. Jakarta: Rajawali Pers

[2] Conference, Singapore, June, 2009

[3] Rakhmat (2005). Rakhmat, Jalaludin. 2005. Psikologi Komunikasi. Bandung: PT. Remaja Rosdakarya

[4] Rasto. 2015. Pembelajaran Mikro Mengembangkan Keterampilan Mengajar Guru Profesional. Bandung: Alfabeta

[5] Slameto, 2003. Belajar dan Faktor-Faktor Yang Mempengaruhinya, Jakarta: Rineka Cipta.

[6] Walgito Bimo. 2002. Pengantar Psikologi Umum. Yogyakarta: Andi Offset

[7] Tri Catharina Anni. 2004. Psikologi Belajar. Semarang: Unnes Press 